\title{
Craniopharyngioma: a roadmap for scientific translation
}

\author{
Saksham Gupta, BA, ${ }^{1}$ Wenya Linda Bi, MD, PhD, ${ }^{1}$ Alexandra Giantini Larsen, BS, ${ }^{1}$ \\ Sally Al-Abdulmohsen, MD, ${ }^{1}$ Malak Abedalthagafi, MD, ${ }^{2}$ and lan F. Dunn, MD'
}

\begin{abstract}
${ }^{1}$ Center for Skull Base and Pituitary Surgery, Department of Neurosurgery, Brigham and Women's Hospital, Harvard Medical School, Boston, Massachusetts; and 2Saudi Human Genome Laboratory, King Fahad Medical City and King Abdulaziz City for Science and Technology, Riyadh, Saudi Arabia
\end{abstract}

OBJECTIVE Craniopharyngiomas are among the most challenging of intracranial tumors to manage because of their pattern of growth, associated morbidities, and high recurrence rate. Complete resection on initial encounter can be curative, but it may be impeded by the risks posed by the involved neurovascular structures. Recurrent craniopharyngiomas, in turn, are frequently refractory to additional surgery and adjuvant radiation or chemotherapy.

METHODS The authors conducted a review of primary literature.

RESULTS Recent advances in the understanding of craniopharyngioma biology have illuminated potential oncogenic targets for pharmacotherapy. Specifically, distinct molecular profiles define two histological subtypes of craniopharyngioma: adamantinomatous and papillary. The discovery of overactive B-Raf signaling in the adult papillary subtype has led to reports of targeted inhibitors, with a growing acceptance for refractory cases. An expanding knowledge of the biological underpinnings of craniopharyngioma will continue to drive development of targeted therapies and immunotherapies that are personalized to the molecular signature of each individual tumor.

CONCLUSIONS The rapid translation of genomic findings to medical therapies for recurrent craniopharyngiomas serves as a roadmap for other challenging neurooncological diseases.

https://thejns.org/doi/abs/10.3171/2018.3.FOCUS1861

KEYWORDS craniopharyngioma; molecular biology; targeted therapy; BRAF; immunotherapy

$\mathrm{C}$ RANIOPHARYNGIOMAS are among the most challenging intracranial lesions to manage surgically and medically. Since the first successful resection over a century ago, innovations in operative technique and endocrinological care have improved the perioperative mortality rate from nearly $100 \%$ to $5 \% .^{8,40,41,73}$ Despite such advances, these tumors still carry a significant risk for recurrence and postoperative morbidity despite aggressive resection and adjuvant radiotherapy when indicated. Recent advances in the understanding of craniopharyngioma pathogenesis offer new promise in the treatment of this disease. The rapid translation of targeted inhibitors into clinical trials for craniopharyngioma serves as a model for therapeutic development for all intracranial tumors.

Craniopharyngioma is thought to arise from squamous cell crests of the embryonic hypophyseal-pharyngeal duct, also known as the craniopharyngeal duct. It represents 3\% of overall and $4 \%$ of childhood cranial tumors, with an annual incidence ranging from 0.05 to 0.20 per $100,000 . .^{14,23,53}$ A bimodal peak incidence is observed between 5-14 years and 65-74 years of age. Two histologically and genomically distinct variants exist: adamantinomatous craniopharyngioma (ACP) and papillary craniopharyngioma (PCP). ${ }^{25}$ ACP is the most common subtype, especially in children, while PCP occurs almost exclusively in adults. ${ }^{18}$

Craniopharyngiomas may manifest with symptoms related to mass effect (e.g., headache, visual loss), hydrocephalus, or endocrine derangements (e.g., stunted growth, hypogonadism, and central diabetes insipidus). They present as mixed solid and cystic radiographic entities (Fig. 1). Gross-total resection is achievable in many cases; when gross-total resection is not achieved, subtotal resection followed by radiotherapy may provide disease control. ${ }^{21,42}$ Innovations in surgical approach and technique, including

ABBREVIATIONS ACP = adamantinomatous craniopharyngioma; ECM = extracellular matrix; EGFR = epidermal growth factor receptor; FGF = fibroblast growth factor; $\mathrm{GH}=$ growth hormone; IFN $\alpha=$ interferon- $\alpha$; IGF = insulin-like growth factor; MAPK = mitogen-activated protein kinase; MMP = matrix metalloproteinases; PCP = papillary craniopharyngioma; RAR = retinoic acid receptor; VEGR = endothelial growth factor.

SUBMITTED February 1, 2018. ACCEPTED March 23, 2018.

INCLUDE WHEN CITING DOI: 10.3171/2018.3.FOCUS1861. 


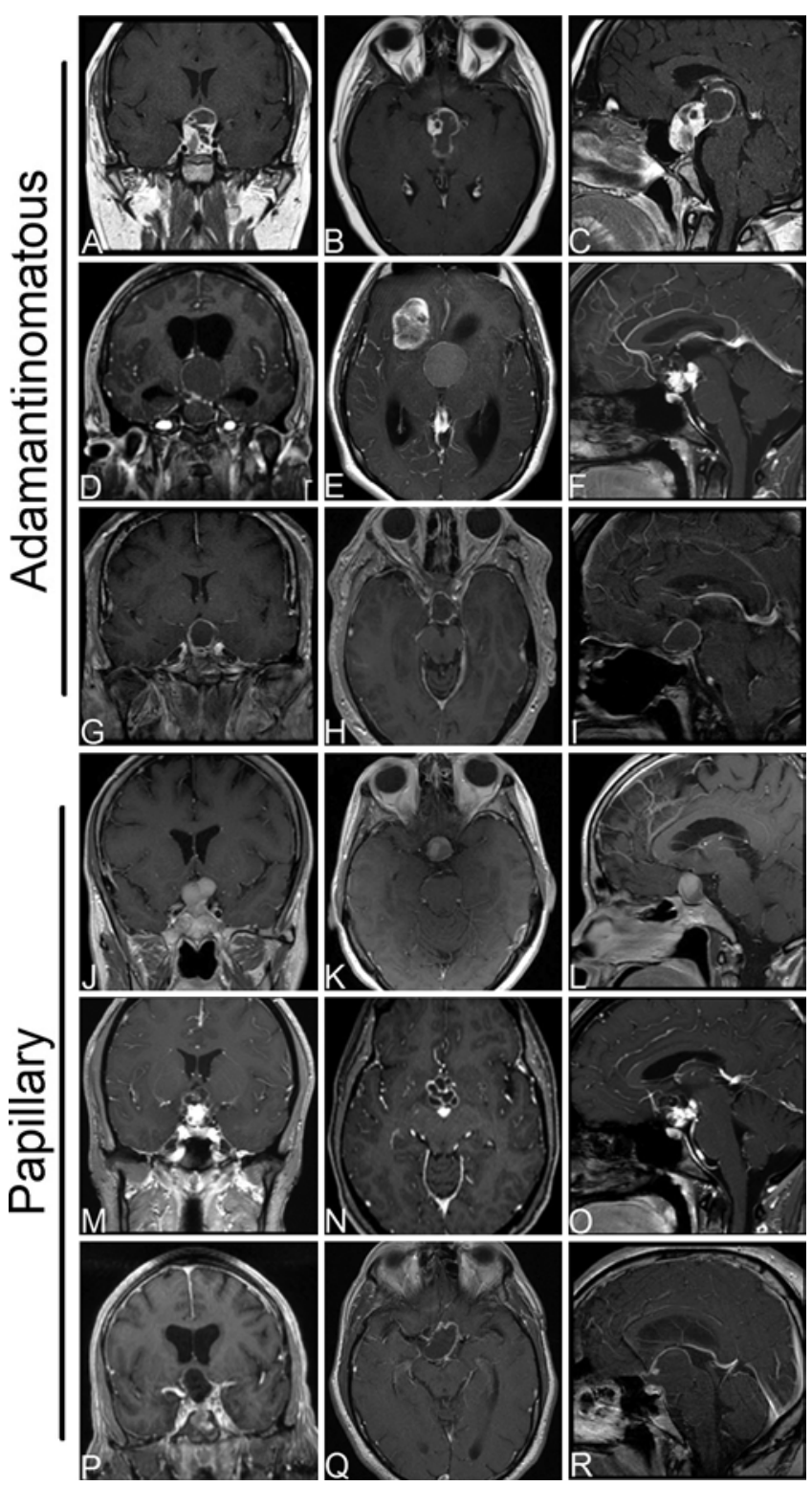

FIG. 1. Craniopharyngiomas manifest with a spectrum of appearances on postcontrast T1-weighted MR images. ACPs (A-I) and PCPs (J-R) are shown.

endoscopic transsphenoidal strategies, have improved the anatomical corridors through which craniopharyngiomas can be resected. . $, 9,20,41$ Nonetheless, recurrence remains a major risk for this pathology. In particular, 20\% of adult craniopharyngioma patients experience further progression after resection of a recurrent tumor. ${ }^{65}$

The risk for panhypopituitarism, hypothalamic dysfunction, hyperphagia leading to obesity, and diabetes insipidus may all increase with more aggressive resection. ${ }^{23,61}$ These and other postoperative morbidities can contribute to a low quality of life for craniopharyngioma patients. ${ }^{28}$ Craniopharyngioma requires multidisciplinary chronic management and presents a burden for childhoodonset patients well into adulthood. Furthermore, the mortality rate is markedly elevated, highlighting the need for additional effective treatment options. ${ }^{19}$

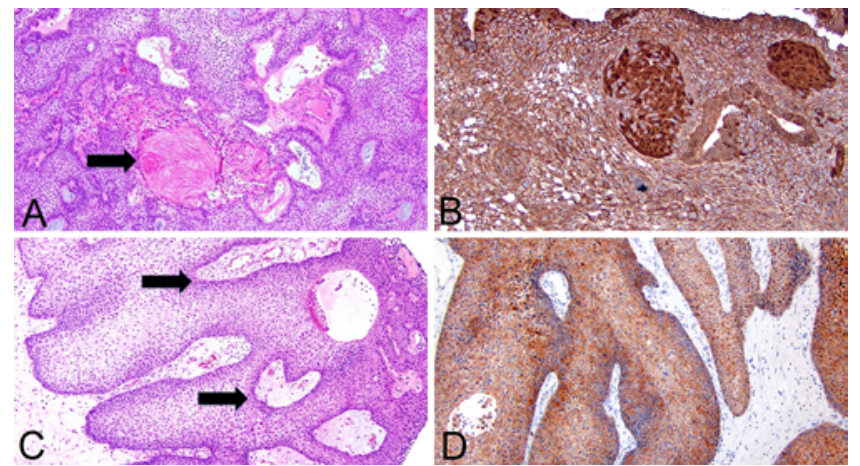

FIG. 2. Histopathological images representative of ACP and PCP. A: ACP demonstrating characteristic microcystic spaces, basal nuclear palisading, stellate reticulin, and "wet keratin" (arrow) with (B) nucleocytoplasmic immunopositivity for B-catenin. C: PCP showing papillary growth pattern with mature nonkeratinizing squamous epithelium lining fibrovascular cores (arrows). D: PCP demonstrating a cytoplasmic immunopositivity $B$-catenin appearance histologically. $\mathrm{H} \& \mathrm{E}$, original magnification $\times 10(A$ and $C)$. B-catenin, original magnification $\times 10(B$ and $D)$.

Radiotherapy has traditionally been the most common neoadjuvant or adjuvant therapy administered to craniopharyngioma patients. For craniopharyngiomas that recur despite resection and radiotherapy, cytotoxic chemotherapy, intracystic drug, and radionucleotide therapies have been trialed. Case series of intracystic administration of bleomycin, a cytotoxic chemotherapy drug, demonstrated it to be well-tolerated and potentially effective in delaying the need for surgery, but its utility has been limited by a potentially serious side effect profile. ${ }^{6}$ Intracystic interferon- $\alpha$ (IFN $\alpha)$ therapy shows efficacy for the cystic, but not solid, components of ACPs. ${ }^{6}$ Systemic cisplatin has also only been reported to produce short-term response. ${ }^{55}$ On the whole, adjuvant options for recurrent and refractory craniopharyngiomas are limited.

In recent years, genomic and molecular biology advances have dramatically accelerated understanding of the pathogenesis of craniopharyngiomas. In this review, we summarize current knowledge of craniopharyngioma genomics and biology with an emphasis on novel targeted therapies.

\section{Papillary Craniopharyngioma \\ Pathogenesis}

PCPs arise almost exclusively in adults and share similar rates of postoperative morbidity as ACP, though some studies suggest that PCP may have a more indolent clinical course. ${ }^{54,63}$ Histological analysis of ACP and PCP reveals differences in cell type and cytokeratin profile (Fig. 2), and their genomic alterations provide a distinct signature for the two subtypes. BRAF mutations have been identified as a signature of most PCPs but not ACPs, while nucleocytoplasmic $\beta$-catenin is characteristic of ACP and is only present in the cytoplasm of PCP cells. ${ }^{24,59}$

\section{B-Raf}

$B R A F$ encodes B-Raf, a cytosolic kinase in the mitogen-activated protein kinase (MAPK) pathway. V600E point mutations in $B R A F$ are rarely found in ACP but 


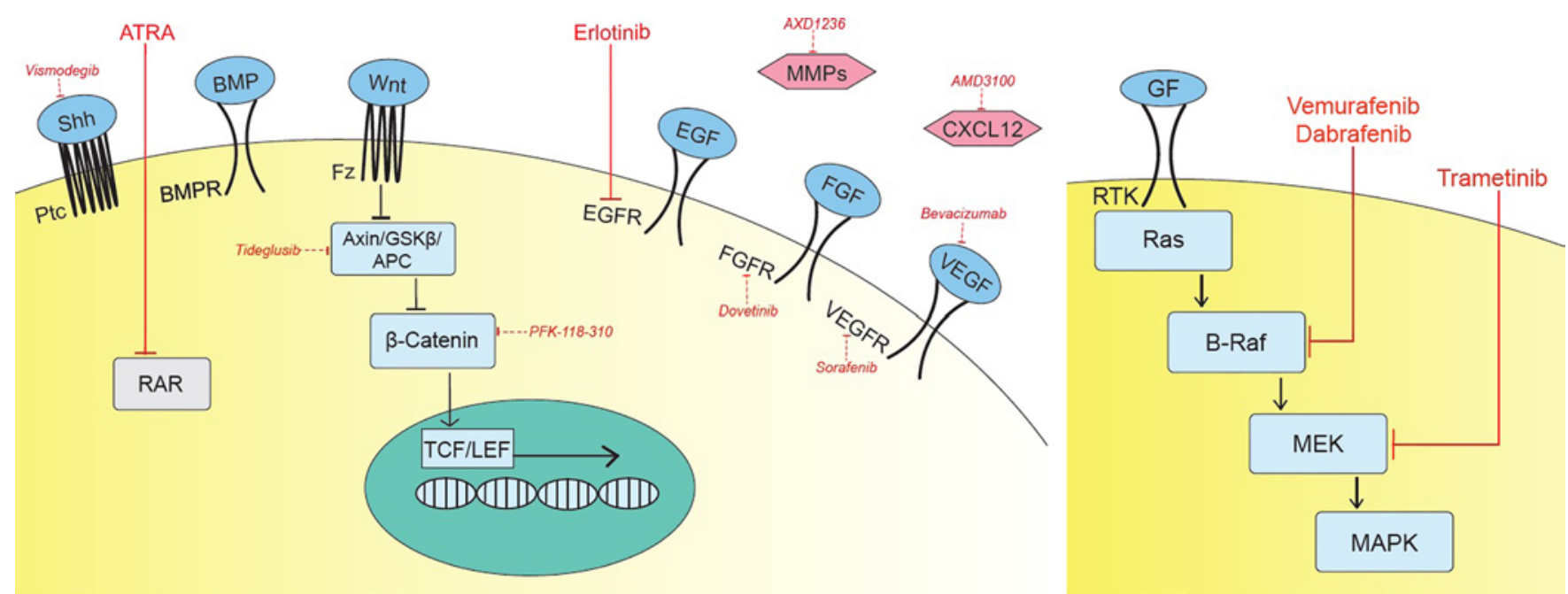

FIG. 3. Pathogenesis of ACP containing areas for drug targeting. Left: The molecular factors that have been implicated in ACP pathogenesis or maintenance are highlighted. Solid red lines represent inhibitors used in preclinical studies, and dashed red lines represent inhibitors proposed for further study based on studied factors. Right: Craniopharyngioma is characterized by aberrant B-Raf activity leading to upregulation of the MAPK pathway. Solid red lines represent small molecular inhibitors that have been tested in case reports of PCP. APC = adenomatous polyposis coli; ATRA = all-trans retinoic acid; BMP = bone morphogenetic protein; $\mathrm{BMPR}=\mathrm{BMP}$ receptor; $\mathrm{CXCL12}=\mathrm{C}-\mathrm{X}-\mathrm{C}$ motif kinase 12; EGF = epidermal growth factor; $\mathrm{EGFR}=\mathrm{EGF}$ receptor; FGF = fibroblast growth factor; FGFR = FGF receptor; Fz = frizzled receptor; GF = growth factor; $G S K \beta=$ glycogen synthase kinase beta; $\mathrm{LEF}=$ lymphoid-enhancer binding factor $1 ; \mathrm{MEK}=$ MAPK kinase; $\mathrm{MMP}=$ matrix metalloprotease; Ptc $=$ patched; $\mathrm{RAR}=$ retinoic acid receptor; $\mathrm{RTK}=$ receptor tyrosine kinase; $\mathrm{Shh}=$ sonic hedgehog; $\mathrm{TCF}=$ transcription factor; $\mathrm{VEGF}=$ vascular endothelial growth factor; VEGFR = VEGF receptor.

were recently discovered to be present in approximately 95\% of PCP cases. ${ }^{12,32,38}$ B-Raf signaling activates the MAPK pathway to promote transcription of prosurvival and growth genes. Hyperactivity of this pathway in PCP can disrupt hormone-producing cell development and encourage proliferation of pituitary stem cells (Fig. 3 left). ${ }^{35}$

This finding holds immediate therapeutic potential, as aberrant B-Raf protein generated by the $B R A F^{\mathrm{V} 600 \mathrm{E}}$ mutation has been targeted in melanoma with the kinase inhibitors vemurafenib and dabrafenib, leading to increases in overall survival. ${ }^{27}$ Targeted therapies against specific molecular drivers of oncogenic growth and survival have led to breakthroughs for multiple cancers; this concept may also be relevant in noncancerous tumors. Given the problem of resistance, testing of dual therapies consisting of dabrafenib and the MAPK kinase (MEK) inhibitor trametinib were conceived to target multiple elements of the MAPK pathway simultaneously. ${ }^{26,69}$

The dramatic response to B-Raf inhibitors in melanoma has motivated 4 reports of targeted inhibitors of B-Raf in PCPs harboring $B R A F^{\mathrm{V} 600 \mathrm{E}}$ mutations (Table 1). ${ }^{5,13}$ Targeted B-Raf inhibitors dramatically reduced tumor volume and symptom burden while remaining well-tolerated by patients in all cases. The first case received one course of vemurafenib, which was discontinued due to a CSF leak produced by rapid tumor volume reduction. ${ }^{5}$ However, this patient experienced recurrence 6 weeks after initiating vemurafenib and showed no response to another trial of the same therapy. In a second case of recurrent PCP, combined dabrafenib and trametinib caused an $85 \%$

TABLE 1. Case reports of targeted therapies for refractory PCPs harboring BRAF ${ }^{\mathrm{V} 600 \mathrm{E}}$

\begin{tabular}{|c|c|c|c|c|c|}
\hline Authors \& Year & $\begin{array}{l}\text { Age (yrs), } \\
\text { Sex }\end{array}$ & $\begin{array}{l}\text { Prior } \\
\text { RT/Op }\end{array}$ & Therapeutic Regimen & $\begin{array}{l}\text { Radiographic } \\
\text { Response }\end{array}$ & Outcome \\
\hline $\begin{array}{l}\text { Brastianos et } \\
\text { al., } 2015\end{array}$ & $39, \mathrm{M}$ & 4 & $\begin{array}{c}\text { Dabrafenib } 150 \text { mg BID for } 21 \text { days; dabrafenib } \\
150 \text { mg BID/trametinib } 2 \text { mg QD for } 52 \text { days }\end{array}$ & PR (85\%) & $\begin{array}{l}\text { In remission } 7 \text { mos after discontinuing } \\
\text { therapy }\end{array}$ \\
\hline $\begin{array}{l}\text { Aylwin et al., } \\
2016\end{array}$ & $57, \mathrm{~F}$ & 4 & Vemurafenib 960 mg BID for 3 mos & PR & $\begin{array}{l}\text { Recurrence } 6 \text { wks after discontinuing } \\
\text { therapy; stable disease after restarting } \\
\text { vemurafenib w/ progression at } 7 \text { mos }\end{array}$ \\
\hline $\begin{array}{l}\text { Roque \& Odia, } \\
\quad 2017\end{array}$ & $47, \mathrm{~F}$ & 3 & $\begin{array}{l}\text { Dabrafenib } 150 \text { BID for } 7 \text { mos; trametinib } 2 \mathrm{mg} \\
\text { QD for } 7 \text { mos }\end{array}$ & PR (>75\%) & In remission 7 mos after therapy \\
\hline $\begin{array}{l}\text { Rostami et al., } \\
2017\end{array}$ & $65, \mathrm{M}$ & 1 & $\begin{array}{c}\text { Dabrafenib } 150 \mathrm{mg} \text { BID for } 21 \text { days; dabrafenib } \\
150 \mathrm{mg} \mathrm{BID/trametinib} 2 \mathrm{mg} \text { QD for } 28 \text { days }\end{array}$ & PR (91\%) & $\begin{array}{l}\text { In remission } 15 \text { wks after discontinuing } \\
\text { therapy }\end{array}$ \\
\hline
\end{tabular}

$\mathrm{BID}=$ twice daily; $\mathrm{PR}=$ positive response (> 50\%); $\mathrm{QD}$ = once daily; $\mathrm{RT}=$ radiotherapy. 
radiographic reduction measured 5 weeks after initiating a therapy-positive radiographic response. ${ }^{13}$ Both cystic and solid components of the tumor decreased with this treatment. Encouraged by the success of dual dabrafenib and trametinib therapy, another group trialed the same regimen in a third case and achieved a 91\% radiographic reduction after 4 weeks of treatment. ${ }^{57} \mathrm{~A}$ fourth case of recurrent $\mathrm{PCP}$ with panhypopituitarism also exhibited remarkable radiographic response and improvement in pituitary function following this same regimen. ${ }^{56}$

\section{Future Directions}

$B R A F$ mutations remain the current focus in PCP cases and require further study. B-Raf inhibition and management of acquired resistance with dual therapy have been studied extensively in melanoma and provide a roadmap for adjuvant therapy for PCP (Fig. 2). Longer-term followup and clinical trials of these inhibitors in PCP will offer most robust evidence of their objective clinical efficacy. Multi-institutional efforts are critical to gathering data on molecular and genetic alterations in PCP, as well as therapeutic outcome data of this rare disease.

\section{Adamantinomatous Craniopharyngioma Pathogenesis}

ACP is histologically characterized by collections of whorl-like nodules consisting of cytokeratin-enriched dysplastic epithelium. ${ }^{49}$ The pathogenic mechanism of ACP is not fully understood, though recent animal model studies suggest a paracrine model in which cells within peripheral nodular structures drive tumorigenesis by signaling nearby epithelial cells of Rathke's pouch origin to proliferate. ${ }^{2,49}$

Proponents of the cancer stem cell model have proposed that tumors populate and repopulate upon recurrence from highly proliferative cancer stem cells. ${ }^{17}$ Interestingly, in vivo studies in mouse and rat ACP models have demonstrated that the pituitary stem cell markers SOX2 and SOX9 are expressed focally in the peripheral nodular clusters but not within the epithelial tumor mass itself. ${ }^{3,29}$ Increased SOX9 expression correlates with recurrence, consistent with a paracrine model in which pituitary stem cells drive dysplastic proliferation of nearby epithelial cells. ${ }^{16}$ This pathogenic model requires further investigation and validation, but provides a framework to consider potential avenues for therapeutic targeting. ${ }^{32}$

\section{Wnt/ß-Catenin Pathway}

$\beta$-catenin is a cytoplasmic protein that mediates gene transcription and cell-cell adhesion. In the absence of the Wnt ligand, $\beta$-catenin undergoes proteasomal degradation as a result of interactions between Axin, glycogen synthase kinase 3 beta (GSK $\beta 3$ ), and anaphase-promoting complex (APC) complex. $\beta$-catenin is prevented from activating the transcription factors T-cell factor (TCF) and lymphoid enhancer factor (LEF). Wnt binds the frizzled receptor $(\mathrm{Fz})$ and initiates a signaling cascade that causes inactivation of the Axin/GSK $\beta 3 / \mathrm{APC}$ complex. In the presence of Wnt, $\beta$-catenin is not degraded and induces TCF/LEF-mediated transcription. This signaling pathway regulates embryonic development, and mutations along the pathway are implicated in multiple disease processes. ${ }^{51}$

The Wnt/ $\beta$-catenin signaling pathway is dysregulated in ACP. Activating mutations in exon 3 of $C T N N B 1$, which encodes the signaling molecule $\beta$-catenin, are found in 94\%-96\% of ACPs. ${ }^{24,59}$ The CTNNB1 mutations observed may carry differential prognostic information. ${ }^{31}$ Nucleocytoplasmic $\beta$-catenin accumulation is a consistent and specific finding in ACP. ${ }^{34}$ A mouse model of ACP has shown that $\beta$-catenin accumulates in epithelial tumor cells even when an activating mutation in CTNNBI is driven exclusively in SOX2-expressing pituitary stem cells localized in peripheral nodules. ${ }^{3}$ This suggests robust paracrine signaling from the peripheral nodular cluster cells to the epithelial cells that comprise the tumor. ${ }^{3}$

Aberrant membranous $\beta$-catenin expression patterns have been associated with worsened outcomes in ACP, so counteracting $\beta$-catenin provides an avenue for therapy. ${ }^{46}$ The ubiquity of Wnt/ $\beta$-catenin dysregulation in other diseases has led to the production of dozens of pharmacological therapies that decrease Wnt $/ \beta$-catenin signaling, including multiple small molecule inhibitors of $\beta$-catenin that could hold promise in the treatment of $\mathrm{ACP}^{70}$

\section{Growth Factor Signaling}

Disrupted growth factor signaling is a hallmark of ACP. Increased expression of epidermal growth factor receptor (EGFR), vascular endothelial growth factor (VEGF), fibroblast growth factor (FGF), growth hormone (GH) receptor, and insulin-like growth factor (IGF) 1 receptor (IGF-1R) have been implicated in this disease. ${ }^{44,68}$ EGFR is immunohistologically detectable in the majority of ACP, and its activated form localizes to peripheral nodular cluster cells. ${ }^{24,36}$ EGFR mRNA is overexpressed in ACP compared to normal pituitary gland and other pituitary tumors. ${ }^{32}$ Gefitinib, an EGFR inhibitor, has been shown to decrease ACP cell motility in vitro by downregulating fascin, a cytoskeletal protein that coordinates cell motility and invasiveness in multiple cancers. ${ }^{1,36} \mathrm{An}$ nexin $\mathrm{A} 2$, a $\mathrm{Ca}^{2+}$-regulated binding protein, expression correlates with gefitinib sensitivity in vitro and may serve as a biomarker to determine which patients will benefit from this therapy. ${ }^{71}$

Recurrence in ACP is associated with increased VEGF expression..$^{62}$ VEGF is a transcriptional target of $\mathrm{Wnt} / \beta$ catenin signaling, and its gene expression is increased in ACP ${ }^{32}$ Further study of the impact of VEGF signaling in ACP will help determine the potential clinical utility of VEGF inhibitors, such as bevacizumab, which have revolutionized cancer management as a first-line therapy across a variety of cancers ${ }^{39,58,67}$ FGF localizes to peripheral nodular cluster cells, is overexpressed in ACP, and correlates with recurrence. ${ }^{2,32,62}$ Its mechanistic significance remains unknown, though the most highly expressed FGF isoform in ACP, FGF4, has been implicated in tumorigenesis and progression in other cancers..$^{74,75}$

GH receptor (GHR) expression is associated with early progression. ${ }^{52,66} \mathrm{GH}$ deficiency commonly presents postoperatively, so increased GH and GHR expression may more likely reflect an adaptive response.$^{15}$ IGF-1R is present on the majority of ACPs. ${ }^{44}$ 


\section{Developmental Morphogenesis}

Bone morphogenetic protein (BMP) and sonic hedgehog (Shh) are paracrine growth-related signaling molecules that play a wide range of developmental and physiological roles. BMP4 is expressed in the peripheral nodular cells in human ACP and mouse models. ${ }^{2,37} \mathrm{ACP}$ is characterized by high gene expression of genes encoding both BMP2 and BMP4, which are downstream of Wnt/ $\beta$-catenin-mediated transcription. ${ }^{7,32}$ The expression of BMP2, which induces bone formation and remodeling, correlates with calcification in ACP. ${ }^{33,60}$ Like BMP4, Shh also localizes to ACP peripheral nodular cluster cells. ${ }^{2}$ Shh signaling pathway genes are overexpressed in ACP as well, and its cleaved active form is highly expressed. ${ }^{32,38}$ Targeted inhibitors of Shh, including vismodegib and sonidegib, have been approved for basal cell carcinoma but have not been studied in craniopharyngioma.

\section{Extracellular Matrix Proteolysis}

Extracellular matrix (ECM) molecules regulate the microenvironment and tumor invasion across many cancers. Matrix metalloproteinases (MMPs) cleave ECM structural proteins such as collagen, fibronectin, elastin, and laminin to contribute to tissue development, remodeling, and repair. ${ }^{50}$ Their ability to alter the ECM environment also enhances the invasive capacity of cancers..$^{22}$ MMP-7 and MMP-9 are transcriptional targets of Wnt/ $\beta$-catenin signaling and their gene expression is elevated in ACP. ${ }^{32}$ Furthermore, gene expression of MMP-12 in craniopharyngioma is elevated 820 -fold over normal pituitary tissue and other pituitary tumors, ${ }^{32}$ while MMP-9 protein expression is increased in recurrent ACP. ${ }^{72}$ Interestingly, while the latent forms of MMP-9 and MMP-12 are present in other pituitary tumors, their cleaved, active forms are present only in ACP. ${ }^{32}$ As novel MMP inhibitors develop, they may serve as therapeutic options to address recurrence in ACP.

\section{Immune Microenvironment}

The importance of the immune microenvironment is increasingly recognized in tumor pathogenesis. For instance, the discovery of increased immune suppression by PD-1 signaling in cancer motivated the development of the anti-PD-1 monoclonal antibody nivolumab, which has been successfully trialed in multiple cancers. ${ }^{4,11,64}$ The microenvironment of ACP has not been extensively characterized, but recent studies suggest disruptions in immune factors within these tumors. C-X-C motif chemokine 12 (CXCL12), a chemokine that activates leukocytes, and its receptor, CXCR4, are present in ACP and demonstrate increased expression in recurrent $\mathrm{ACP} \cdot{ }^{30} \mathrm{CXCL} 12$ attracts lymphocytes robustly, but despite increased CXCL12 signaling in recurrent ACP, these lymphocytes are unable to suppress recurrence. ${ }^{10}$ This implies that recurrent $\mathrm{ACP}$ harbors an intrinsic mechanism to suppress the immune response. Expression of the interleukin-2 (IL2) receptor (IL2R), which is normally present on lymphocytes to bind the IL2 chemokine, is increased in ACP, suggesting that sequestration of IL2 may be another mechanism of immune evasion. ${ }^{32}$ The IL2R expression may instead reflect lymphocyte infiltration into the study's ACP sample, suggesting that immune cells can localize to ACP but are rendered ineffective through checkpoint inhibition or another mechanism. Proteomic analysis of ACP cystic fluid reveals the presence of multiple inflammatory markers. ${ }^{48}$

\section{Retinoic Acid Receptor}

In addition to the aforementioned disruptions, ACP demonstrates immunoreactivity to retinoic acid receptors (RARs) RAR $\alpha$, RAR $\beta$, and RAR $\gamma$, and the ratio of RAR $\gamma /$ RAR $\beta$ immunoreactivity correlates with recurrence. ${ }^{43}$ All-trans retinoic acid (ATRA), the substrate of RAR, induces ACP cellular apoptosis in vitro. ${ }^{45}$ The presence of cathepsin $\mathrm{K}$, a lysosomal cysteine protease, correlates with RAR $\gamma$ immunoreactivity and may be a downstream effector of RAR $\gamma$ signaling. ${ }^{47}$

\section{Future Directions}

Recent studies have partially clarified the pathogenesis of ACP, including the role of paracrine signaling of growth factors and microenvironment elements. Many of these findings include aberrancies that can be targeted with existing drugs, including therapies targeting $\beta$-catenin, EGFR, and VEGF (Fig. 3 right).

Most importantly, the adamantinomatous subtype, like its papillary counterpart, is characterized by a defining genetic alteration: the majority of cases harbor CTNNBI mutations. However, a significant difference is that this alteration is not readily targetable. In this way, craniopharyngioma is a vignette of the promise and the challenge of the application of contemporary genomics approaches to identify therapeutic targets. PCPs illustrate the promisedetection of a known pathogenic allele (BRAF V600E) in nearly all tumors for which a widely used inhibitor is deployable-while the much more common ACP demonstrates the challenge, in which nearly all tumors are found to harbor a mutation that, though alluring, is currently untargetable.

\section{Discussion}

Management of craniopharyngioma remains difficult despite significant advances in operative technique, adjuvant therapies including radiotherapy, and medical management. Patient quality of life is significantly affected by significant metabolic and endocrine disturbances, neurocognitive and psychological sequelae, and the high risk of recurrence. The burden of craniopharyngioma on society in terms of years of productivity lost is especially large, given that the majority of cases are ACPs that have an early age of onset. Advances in therapeutics are needed to combat this aggressive disease.

While there are a variety of adjuvant therapies for craniopharyngioma that provide additional therapeutic response, including the use of bleomycin and IFNa, the morbidity rates for ACP and PCP remain significant. An alternatively alluring concept is the use of genomic tumor data to curate targets for therapy. By targeting the fundamental biological drivers of craniopharyngioma, these therapies hold promise for substantial effects on tumor growth and regrowth. A barrier for the development of 
targeted therapies for craniopharyngioma may also trigger positive selection of resistant cancer cells, leading to tumor recurrence. Multidrug regimens combat this phenomenon and have been shown to delay disease relapse. ${ }^{26}$

Detailed genomic and molecular studies of ACP have begun to uncover the complex pathogenic nature of the disease. Histological studies suggest that ACPs arise from oral epithelial cells in the anterior pituitary in response to aberrant growth factor signaling from nearby pituitary stem cells. These stem cells are concentrated in peripheral nodular clusters. In ACP, overactive $\beta$-catenin signaling due to mutations in exon 3 of $C T N N B 1$ prompts the transcription of growth, morphogenetic, and ECM factors that then drive disease progression. Each point along this pathway provides an opportunity for therapeutic targeting, and inhibitors of $\beta$-catenin, EGFR, VEGF, RARs, and MMPs have been developed for and tested in patients with other cancers. Studies of these inhibitors on animal models of ACP are necessary to determine which therapies will be most effective, and in the pursuit of personalizing medication regiments, the histological and genomic profiles of each ACP should guide its management.

Genomic studies of PCP reveal that V600E mutations in $B R A F$ cause the overactive B-Raf to upregulate transcription via the MAPK pathway. This exact mutation also drives melanoma growth and consequently, has motivated the development of targeted kinase inhibitors against B-Raf as well as inhibitors to use for recurrent tumors containing therapy-resistant mutations. Usage of targeted therapy against B-Raf has been reported in four PCPs with positive response, with its long-term efficacy to be determined in larger-scale clinical trials.

\section{Conclusions}

Craniopharyngioma is a complex tumor from both a surgical and medical standpoint. Novel operative techniques have brought the field closer toward safe gross-total resection, but studies into craniopharyngioma biology are necessary to combat tumor progression and recurrence. Major advances in the field of targeted therapies for use in oncology have recently been made. Coupled with new insight into craniopharyngioma pathogenesis with regard to genomic and molecular alterations, targeted therapeutics hold promise for clinical utility against this aggressive disease. Their validation, order of use in the sequence of contemporary treatment options, durability, and associated resistance susceptibility are just some of the major questions to be answered as targeted therapies for craniopharyngioma moves from promise to practice.

\section{References}

1. Adams JC: Roles of fascin in cell adhesion and motility. Curr Opin Cell Biol 16:590-596, 2004

2. Andoniadou CL, Gaston-Massuet C, Reddy R, Schneider RP, Blasco MA, Le Tissier P, et al: Identification of novel pathways involved in the pathogenesis of human adamantinomatous craniopharyngioma. Acta Neuropathol 124:259-271, 2012

3. Andoniadou CL, Matsushima D, Mousavy Gharavy SN, Signore M, Mackintosh AI, Schaeffer M, et al: Sox $2^{+}$stem/ progenitor cells in the adult mouse pituitary support organ homeostasis and have tumor-inducing potential. Cell Stem Cell 13:433-445, 2013

4. Ansell SM, Lesokhin AM, Borrello I, Halwani A, Scott EC, Gutierrez M, et al: PD-1 blockade with nivolumab in relapsed or refractory Hodgkin's lymphoma. N Engl J Med 372:311319,2015

5. Aylwin SJ, Bodi I, Beaney R: Pronounced response of papillary craniopharyngioma to treatment with vemurafenib, a BRAF inhibitor. Pituitary 19:544-546, 2016

6. Bailey S, Parkes J: Intracystic interferon therapy in childhood craniopharyngioma: who, when and how? Clin Endocrinol (Oxf) 82:29-34, 2015

7. Baker JC, Beddington RS, Harland RM: Wnt signaling in Xenopus embryos inhibits bmp4 expression and activates neural development. Genes Dev 13:3149-3159, 1999

8. Barkhoudarian G, Laws ER: Craniopharyngioma: history. Pituitary 16:1-8, 2013

9. Bi WL, Laws ER Jr, Dunn IF: The microscopic transsphenoidal approach for craniopharyngiomas, in Kenning TJ, Evans JJ (eds): Craniopharyngiomas, Comprehensive Diagnosis, Treatment and Outcome. Oxford, UK: Academic Press, 2015, pp 165-181

10. Bleul CC, Fuhlbrigge RC, Casasnovas JM, Aiuti A, Springer TA: A highly efficacious lymphocyte chemoattractant, stromal cell-derived factor 1 (SDF-1). J Exp Med 184:11011109, 1996

11. Brahmer J, Reckamp KL, Baas P, Crinò L, Eberhardt WE, Poddubskaya E, et al: Nivolumab versus docetaxel in advanced squamous-cell non-small-cell lung cancer. N Engl J Med 373:123-135, 2015

12. Brastianos PK, Santagata S: Endocrine tumors: BRAF V600E mutations in papillary craniopharyngioma. Eur J Endocrinol 174:R139-R144, 2016

13. Brastianos PK, Shankar GM, Gill CM, Taylor-Weiner A, Nayyar N, Panka DJ, et al: Dramatic response of BRAF V600E mutant papillary craniopharyngioma to targeted therapy. J Natl Cancer Inst 108:djv310, 2015

14. Bunin GR, Surawicz TS, Witman PA, Preston-Martin S, Davis F, Bruner JM: The descriptive epidemiology of craniopharyngioma. Neurosurg Focus 3(6):e1, 1997

15. Chakrabarti I, Amar AP, Couldwell W, Weiss MH: Longterm neurological, visual, and endocrine outcomes following transnasal resection of craniopharyngioma. J Neurosurg 102:650-657, 2005

16. Chang CV, Araujo RV, Cirqueira CS, Cani CM, Matushita H, Cescato VA, et al: Differential expression of stem cell markers in human adamantinomatous craniopharyngioma and pituitary adenoma. Neuroendocrinology 104:183-193, 2017

17. Clevers H: The cancer stem cell: premises, promises and challenges. Nat Med 17:313-319, 2011

18. Crotty TB, Scheithauer BW, Young WF Jr, Davis DH, Shaw EG, Miller GM, et al: Papillary craniopharyngioma: a clinicopathological study of 48 cases. J Neurosurg 83:206-214, 1995

19. Crowley RK, Hamnvik OP, O'Sullivan EP, Behan LA, Smith $\mathrm{D}$, Agha A, et al: Morbidity and mortality in patients with craniopharyngioma after surgery. Clin Endocrinol (Oxf) 73:516-521, 2010

20. de Divitiis E, Cappabianca P, Cavallo LM, Esposito F, de Divitiis O, Messina A: Extended endoscopic transsphenoidal approach for extrasellar craniopharyngiomas. Neurosurgery 61 (5 Suppl 2):219-228, 2007

21. Duff J, Meyer FB, Ilstrup DM, Laws ER Jr, Schleck CD, Scheithauer BW: Long-term outcomes for surgically resected craniopharyngiomas. Neurosurgery 46:291-305, 2000

22. Egeblad M, Werb Z: New functions for the matrix metalloproteinases in cancer progression. Nat Rev Cancer 2:161174, 2002

23. Erfurth EM, Holmer H, Fjalldal SB: Mortality and morbidity in adult craniopharyngioma. Pituitary 16:46-55, 2013 
24. Esheba GE, Hassan AA: Comparative immunohistochemical expression of $\beta$-catenin, EGFR, ErbB2, and p63 in adamantinomatous and papillary craniopharyngiomas. J Egypt Natl Canc Inst 27:139-145, 2015

25. Fernandez-Miranda JC, Gardner PA, Snyderman CH, Devaney KO, Strojan P, Suárez C, et al: Craniopharyngioma: a pathologic, clinical, and surgical review. Head Neck 34:1036-1044, 2012

26. Flaherty KT, Infante JR, Daud A, Gonzalez R, Kefford RF, Sosman J, et al: Combined BRAF and MEK inhibition in melanoma with BRAF V600 mutations. N Engl J Med 367:1694-1703, 2012

27. Flaherty KT, Puzanov I, Kim KB, Ribas A, McArthur GA, Sosman JA, et al: Inhibition of mutated, activated BRAF in metastatic melanoma. N Engl J Med 363:809-819, 2010

28. Foreman NK, Faestel PM, Pearson J, Disabato J, Poole M, Wilkening G, et al: Health status in 52 long-term survivors of pediatric brain tumors. J Neurooncol 41:47-53, 1999

29. Garcia-Lavandeira M, Saez C, Diaz-Rodriguez E, PerezRomero S, Senra A, Dieguez C, et al: Craniopharyngiomas express embryonic stem cell markers (SOX2, OCT4, KLF4, and SOX9) as pituitary stem cells but do not coexpress RET/ GFRA3 receptors. J Clin Endocrinol Metab 97:E80-E87, 2012

30. Gong J, Zhang H, Xing S, Li C, Ma Z, Jia G, et al: High expression levels of CXCL12 and CXCR4 predict recurrence of adamanti-nomatous craniopharyngiomas in children. Cancer Biomark 14:241-251, 2014

31. Goschzik T, Gessi M, Dreschmann V, Gebhardt U, Wang L, Yamaguchi S, et al: Genomic alterations of adamantinomatous and papillary craniopharyngioma. J Neuropathol Exp Neurol 76:126-134, 2017

32. Gump JM, Donson AM, Birks DK, Amani VM, Rao KK, Griesinger AM, et al: Identification of targets for rational pharmacological therapy in childhood craniopharyngioma. Acta Neuropathol Commun 3:30, 2015

33. Hassan MQ, Tare RS, Lee SH, Mandeville M, Morasso MI, Javed A, et al: BMP2 commitment to the osteogenic lineage involves activation of Runx 2 by DLX3 and a homeodomain transcriptional network. J Biol Chem 281:40515-40526, 2006

34. Hassanein AM, Glanz SM, Kessler HP, Eskin TA, Liu C: $\beta$ Catenin is expressed aberrantly in tumors expressing shadow cells. Pilomatricoma, craniopharyngioma, and calcifying odontogenic cyst. Am J Clin Pathol 120:732-736, 2003

35. Haston S, Pozzi S, Carreno G, Manshaei S, Panousopoulos L, Gonzalez-Meljem JM, et al: MAPK pathway control of stem cell proliferation and differentiation in the embryonic pituitary provides insights into the pathogenesis of papillary craniopharyngioma. Development 144:2141-2152, 2017

36. Hölsken A, Gebhardt M, Buchfelder M, Fahlbusch R, Blümcke I, Buslei R: EGFR signaling regulates tumor cell migration in craniopharyngiomas. Clin Cancer Res 17:4367-4377, 2011

37. Hölsken A, Kreutzer J, Hofmann BM, Hans V, Oppel F, Buchfelder M, et al: Target gene activation of the Wnt signaling pathway in nuclear $\beta$-catenin accumulating cells of adamantinomatous craniopharyngiomas. Brain Pathol 19:357-364, 2009

38. Hölsken A, Sill M, Merkle J, Schweizer L, Buchfelder M, Flitsch J, et al: Adamantinomatous and papillary craniopharyngiomas are characterized by distinct epigenomic as well as mutational and transcriptomic profiles. Acta Neuropathol Commun 4:20, 2016

39. Hurwitz H, Fehrenbacher L, Novotny W, Cartwright T, Hainsworth J, Heim W, et al: Bevacizumab plus irinotecan, fluorouracil, and leucovorin for metastatic colorectal cancer. N Engl J Med 350:2335-2342, 2004

40. Laws ER Jr: Transsphenoidal microsurgery in the management of craniopharyngioma. J Neurosurg 52:661-666, 1980
41. Laws ER Jr: Transsphenoidal removal of craniopharyngioma. Pediatr Neurosurg 21 (Suppl 1):57-63, 1994

42. Laws ER, Weiss MH, White WL: Craniopharyngioma. Skull Base 13:55-58, 2003

43. Lefranc F, Chevalier C, Vinchon M, Dhellemmes P, Schüring MP, Kaltner H, et al: Characterization of the levels of expression of retinoic acid receptors, galectin-3, macrophage migration inhibiting factor, and p53 in 51 adamantinomatous craniopharyngiomas. J Neurosurg 98:145-153, 2003

44. Li Q, You C, Liu L, Rao Z, Sima X, Zhou L, et al: Craniopharyngioma cell growth is promoted by growth hormone $(\mathrm{GH})$ and is inhibited by tamoxifen: involvement of growth hormone receptor (GHR) and IGF-1 receptor (IGF-1R). J Clin Neurosci 20:153-157, 2013

45. Li Q, You C, Zhou L, Sima X, Liu Z, Liu H, et al: All-trans retinoic acid inhibits craniopharyngioma cell growth: study on an explant cell model. J Neurooncol 112:355-364, 2013

46. Li Z, Xu J, Huang S, You C: Aberrant membranous expression of $\beta$-catenin predicts poor prognosis in patients with craniopharyngioma. Ann Diagn Pathol 19:403-408, 2015

47. Lubansu A, Ruchoux MM, Brotchi J, Salmon I, Kiss R, Lefranc F: Cathepsin B, D and K expression in adamantinomatous craniopharyngiomas relates to their levels of differentiation as determined by the patterns of retinoic acid receptor expression. Histopathology 43:563-572, 2003

48. Martelli C, Iavarone F, Vincenzoni F, Rossetti DV, D’Angelo L, Tamburrini G, et al: Proteomic characterization of pediatric craniopharyngioma intracystic fluid by LC-MS top-down/ bottom-up integrated approaches. Electrophoresis 35:21722183,2014

49. Martinez-Barbera JP, Buslei R: Adamantinomatous craniopharyngioma: pathology, molecular genetics and mouse models. J Pediatr Endocrinol Metab 28:7-17, 2015

50. Nagase H, Woessner JF Jr: Matrix metalloproteinases. J Biol Chem 274:21491-21494, 1999

51. Nusse R: Wnt signaling in disease and in development. Cell Res 15:28-32, 2005

52. Ogawa Y, Watanabe M, Tominaga T: Prognostic factors of craniopharyngioma with special reference to autocrine/paracrine signaling: underestimated implication of growth hormone receptor. Acta Neurochir (Wien) 157:1731-1740, 2015

53. Ostrom QT, Gittleman H, Farah P, Ondracek A, Chen Y, Wolinsky Y, et al: CBTRUS statistical report: Primary brain and central nervous system tumors diagnosed in the United States in 2006-2010. Neuro Oncol 15 (Suppl 2):ii1-ii56, 2013

54. Pekmezci M, Louie J, Gupta N, Bloomer MM, Tihan T: Clinicopathological characteristics of adamantinomatous and papillary craniopharyngiomas: University of California, San Francisco experience 1985-2005. Neurosurgery 67:13411349,2010

55. Plowman PN, Besser GM, Shipley J, Summersgill B, Geddes J, Afshar F: Dramatic response of malignant craniopharyngioma to cis-platin-based chemotherapy. Should craniopharyngioma be considered as a suprasellar 'germ cell' tumour? Br J Neurosurg 18:500-505, 2004

56. Roque A, Odia Y: BRAF-V600E mutant papillary craniopharyngioma dramatically responds to combination BRAF and MEK inhibitors. CNS Oncol 6:95-99, 2017

57. Rostami E, Witt Nyström P, Libard S, Wikström J, CasarBorota O, Gudjonsson O: Recurrent papillary craniopharyngioma with BRAFV600E mutation treated with neoadjuvanttargeted therapy. Acta Neurochir (Wien) 159:2217-2221, 2017

58. Sandler A, Gray R, Perry MC, Brahmer J, Schiller JH, Dowlati A, et al: Paclitaxel-carboplatin alone or with bevacizumab for non-small-cell lung cancer. N Engl J Med 355:2542-2550, 2006

59. Sekine S, Shibata T, Kokubu A, Morishita Y, Noguchi M, Nakanishi Y, et al: Craniopharyngiomas of adamantinoma- 
tous type harbor beta-catenin gene mutations. Am J Pathol 161:1997-2001, 2002

60. Song-Tao Q, Xiao-Rong Y, Jun P, Yong-Jian D, Jin L, GuangLong H, et al: Does the calcification of adamantinomatous craniopharyngioma resemble the calcium deposition of osteogenesis/odontogenesis? Histopathology 64:336-347, 2014

61. Sughrue ME, Yang I, Kane AJ, Fang S, Clark AJ, Aranda D, et al: Endocrinologic, neurologic, and visual morbidity after treatment for craniopharyngioma. J Neurooncol 101:463476, 2011

62. Sun HI, Akgun E, Bicer A, Ozkan A, Bozkurt SU, Kurtkaya $\mathrm{O}$, et al: Expression of angiogenic factors in craniopharyngiomas: implications for tumor recurrence. Neurosurgery 66:744-750, 2010

63. Tavangar SM, Larijani B, Mahta A, Hosseini SM, Mehrazine M, Bandarian F: Craniopharyngioma: a clinicopathological study of 141 cases. Endocr Pathol 15:339-344, 2004

64. Topalian SL, Sznol M, McDermott DF, Kluger HM, Carvajal RD, Sharfman WH, et al: Survival, durable tumor remission, and long-term safety in patients with advanced melanoma receiving nivolumab. J Clin Oncol 32:1020-1030, 2014

65. Turel MK, Tsermoulas G, Gonen L, Klironomos G, Almeida JP, Zadeh G, et al: Management and outcome of recurrent adult craniopharyngiomas: an analysis of 42 cases with longterm follow-up. Neurosurg Focus 41(6):E11, 2016

66. Ulfarsson E, Karström A, Yin S, Girnita A, Vasilcanu D, Thoren M, et al: Expression and growth dependency of the insulin-like growth factor I receptor in craniopharyngioma cells: a novel therapeutic approach. Clin Cancer Res 11:4674-4680, 2005

67. Valachis A, Polyzos NP, Patsopoulos NA, Georgoulias V, Mavroudis D, Mauri D: Bevacizumab in metastatic breast cancer: a meta-analysis of randomized controlled trials. Breast Cancer Res Treat 122:1-7, 2010

68. Vaquero J, Zurita M, de Oya S, Coca S, Morales C, Salas C: Expression of vascular permeability factor in craniopharyngioma. J Neurosurg 91:831-834, 1999

69. Villanueva J, Vultur A, Herlyn M: Resistance to BRAF inhibitors: unraveling mechanisms and future treatment options. Cancer Res 71:7137-7140, 2011

70. Voronkov A, Krauss S: Wnt/beta-catenin signaling and small molecule inhibitors. Curr Pharm Des 19:634-664, 2013
71. Wang Y, Deng J, Guo G, Tong A, Peng X, Chen H, et al: Clinical and prognostic role of annexin A2 in adamantinomatous craniopharyngioma. J Neurooncol 131:21-29, 2017

72. Xia Z, Liu W, Li S, Jia G, Zhang Y, Li C, et al: Expression of matrix metalloproteinase-9, type IV collagen and vascular endothelial growth factor in adamantinous craniopharyngioma. Neurochem Res 36:2346-2351, 2011

73. Yaşargil MG, Curcic M, Kis M, Siegenthaler G, Teddy PJ, Roth P: Total removal of craniopharyngiomas. Approaches and long-term results in 144 patients. J Neurosurg 73:3-11, 1990

74. Yasuda K, Torigoe T, Mariya T, Asano T, Kuroda T, Matsuzaki J, et al: Fibroblasts induce expression of FGF4 in ovarian cancer stem-like cells/cancer-initiating cells and upregulate their tumor initiation capacity. Lab Invest 94:1355-1369, 2014

75. Zaharieva BM, Simon R, Diener PA, Ackermann D, Maurer $\mathrm{R}$, Alund $\mathrm{G}$, et al: High-throughput tissue microarray analysis of 11q13 gene amplification (CCND1, FGF3, FGF4, EMS1) in urinary bladder cancer. J Pathol 201:603-608, 2003

\section{Disclosures}

The authors report no conflict of interest concerning the materials or methods used in this study or the findings specified in this paper.

\section{Author Contributions}

Conception and design: Dunn, Gupta, Bi. Acquisition of data: Gupta, Abedalthagafi. Analysis and interpretation of data: all authors. Drafting the article: Dunn, Gupta, Bi, Giantini Larsen, Al-Abdulmohsen. Critically revising the article: Dunn, Gupta, Bi, Giantini Larsen, Abedalthagafi. Reviewed submitted version of manuscript: all authors. Approved the final version of the manuscript on behalf of all authors: Dunn. Administrative/technical/ material support: Abedalthagafi.

\section{Correspondence}

Ian F. Dunn: Brigham and Women's Hospital, Boston, MA. idunn@bwh.harvard.edu. 